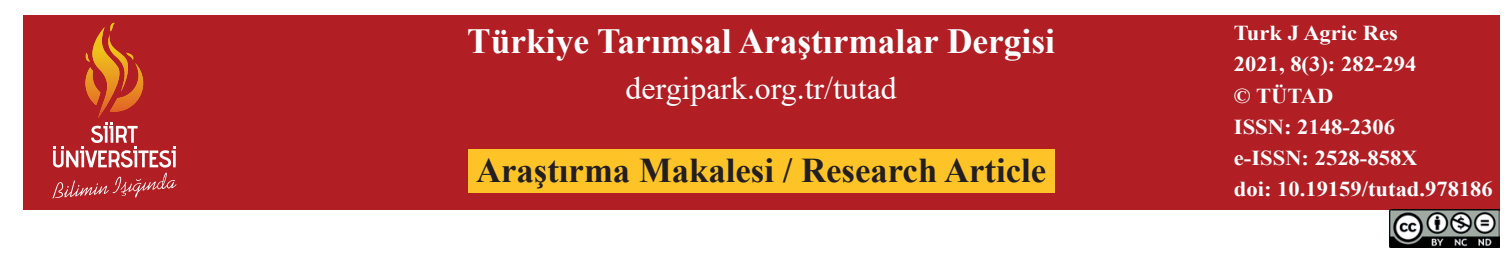

\title{
İncir (Ficus carica L.) Genotipleri Arasındaki Fenotipik Varyasyonun Kümeleme ve Temel Bileşen Analizi Metodu İle Belirlenmesi
}

\author{
Adnan DOĞAN ${ }^{1}$, Haydar KURT ${ }^{1}$, Koray ÖZRENK ${ }^{2 *}$ \\ ${ }^{\prime}$ Van Yüzüncü Yll Üniversitesi, Ziraat Fakültesi, Bahçe Bitkileri Bölümü, Van, TÜUKIYYE \\ ${ }^{2}$ Siirt Üniversitesi, Ziraat Fakültesi, Bahçe Bitkileri Bölümü, Siirt, TÜRKIYE
}

\begin{tabular}{|c|c|}
\hline Geliş Tarihi/Received: 04.08.2021 & Kabul Tarihi/Accepted: 03.12.2021 \\
\hline \multicolumn{2}{|l|}{ ORCID ID (Yazar sirasina göre / by author order) } \\
\hline \multicolumn{2}{|c|}{ (1D)orcid.org/0000-0002-8623-0629 (D) orcid.org/0000-0002-4637-1996 (1D) orcid.org/0000-0002-6692-2337 } \\
\hline
\end{tabular}

"Sorumlu Yazar/Corresponding Author: korayozrenk@hotmail.com

Öz: İncir (Ficus carica L.), dünyada yaygın olarak yetiştirilen en eski kutsal meyvelerdendir. Güneydoğu Anadolu'nun, incir gen merkezi olarak özel bir yere sahip olduğu bilinmektedir. Bu araştırmada, Siirt (Türkiye) yöresinde yetiştirilen incir $(F$. carica L.) genotiplerinin 21 kalitatif ve kantitatif özellikleri değerlendirilmiştir. Bu çalışma ile incir genotiplerinin fenotipik karakterizasyonu yapılmış olup, incelenen genotipler arasında yüksek düzeyde fenotipik çeşitlilik saptanmıştır. İncelenen özelliklerin çoğunun varyasyon katsayısı (VK) \% 20.00'dan yüksek bulunmuş olup, parametrelerin VK değerleri \% 10.7962.78 aralığında değişkenlik göstermiştir. İrdelenen karakterlerin birbiriyle olan ilişki düzeyleri ile her bir faktörün incir meyvesini tanımlamadaki etki oranları belirlenmiştir. En yüksek kaliteye sahip genotiplerin; E-42, E-19, E-26, E-27, E-30 ve E-20 olduğu belirlenmiștir. Mevcut çalışmanın sonuçları, incir genetik kaynaklarının uygun bir şekilde yönetilmesi ve korunması bağlamında özgün bir değere sahiptir. Üzerinde çalışılan genotiplerin gelecekteki ıslah programları için önemli bir gen kaynağı olabileceği düşünülmektedir.

Anahtar Kelimeler: İncir, Ficus carica, korelasyon analizi, çok değişkenli analiz

\section{Determination of Phenotypic Variation Among Fig (Ficus carica L.) Genotypes by Clustering and Principal Component Analysis Method}

\begin{abstract}
Fig (Ficus carica L.) is one of the oldest sacred fruits widely grown in the world. Southeastern Anatolia is known to have a special place as a fig gene center. In this study, 21 qualitative and quantitative properties of fig genotypes grown in the Siirt (Turkey) region were evaluated. In this study, phenotypic characterization of fig genotypes was made and a high level of phenotypic diversity was detected among the genotypes examined. The coefficient of variation (CV) of most of the traits examined was found to be higher than $20.00 \%$, and the CV values of the parameters were ranged between $10.79 \%$ to $62.78 \%$. The correlation levels of the examined traits and the effect ratios of each factor in defining the fig fruit were determined. The genotypes with the highest quality were determined as E-42, E-19, E-26, E-27, E-30, and E-20. The results of the current study have a unique value in the context of proper management and conservation of the fig genetic resources. It is thought that the studied genotypes can be an important source of genes for future breeding programs.
\end{abstract}

Keywords: Fig, Ficus carica L., correlation, multivariate analysis

\section{Giriş}

İncir (Ficus carica L.) türünün de içinde bulunduğu Moraceae (Dutgiller) familyasında, yaklaşık 1400 'den fazla tür bulunmaktadır. Ficus cinsi bünyesinde ortalama 800 tür barındırmaktadır (Frodin, 2004). İncir, Batı Asya’ya özgü bir meyve olup daha sonra Akdeniz bölgesine yayılmıştır. Kislev ve ark. (2006)'na göre, incir ağaçları muhtemelen tahıllardan yaklaşık bin yıl 
önce Neolitik dönemin ilk kültüre alınmış meyvelerindedir. Subtropikal bir meyve olmasina rağmen, yüksek adaptasyon kabiliyetine sahip incirler, 1lıman iklim bölgesinde de yaygın olarak yetiştirilmektedir (Kaşka ve ark., 1992). Yetiştiriciliğinin yapılmadığı yerlerde incir, egzotik meyve olarak kabul edilmiştir (Aksoy ve ark., 2003).

İncir için Doğu Akdeniz Bölgesi, kültüre alındığı ve yetiştiriciliğinin yapıldığı alan olarak kabul görmektedir. Akdeniz ülkeleri başlıca incir üreticileri olup; Türkiye, toplam dünya üretiminin \% 26.8'ini karşılamaktadır. İncir taze veya kurutulmuş olarak tüketilmekte; tıbbi ve biyoaktif özellikleri ve Akdeniz diyetinin önemli bileşeni olması nedeniyle de geleneksel tıpta da yaygın olarak kullanılmaktadır (Tous ve Ferguson, 1996; Solomon ve ark., 2006; Falistocco, 2009; Gozlekci, 2010; Crisosto ve ark., 2011; Ercisli ve ark., 2012; Gürbüz ve ark., 2018).

Türkiye iklim, toprak, ekolojik farklılığ nedeniyle zengin bir incir çeşitliliğine sahip olup; yetiştiricilik kapasitesi açısından dünya genelinde ilk sıralarda yer almaktadır. Bașta Aydın ili olmak üzere, Ege Bölgesi'nde üretimi yapılan Sarılop inciri, dünyada yüksek kalitesi ile tanınmaktadır. Türkiye incir üretiminde sofralık incirler, kurutmalık incirler kadar rağbet görmemiştir (Aksoy ve ark., 2003). İncir lezzetli bir meyve olmasının yanı sıra vitamin, protein, mineral ve lif bakımından da zengin bir içeriğe sahiptir (Uzun ve Yarılgaç, 2021). Türkiye'de zengin incir çeşitliliği bulunmasına karşılık, maalesef sofralık incir üretimi Bursa ili ve çevresi dıșında hak ettiği değeri görmemektedir. Ancak son yıllarda, incirin besin değerlerinin ve öneminin anlaşılması, taze meyve nakliye imkânlarının artması, incir meyvesine uygun ambalajların geliştirilmesi, sofralık incirlerin de dış piyasaya arzını kolaylaştırarak talebi artırmıştır.

Güneydoğu Anadolu Bölgesi zengin incir formlarını bünyesinde barındırmakta; Siirt (Botansuyu Havzası), Diyarbakır, Elâzı ğ, Gaziantep, Kahramanmaraş illeri ve Ceyhan Havzası'nda incirin çeşitli kültür ve yabani formları bulunmaktadır (Simsek ve ark., 2017). Bu nedenle Güneydoğu Anadolu Bölgesi incir gen merkezi olarak özel bir konuma sahiptir (Ilgın, 1995; Simsek, 2009). Siirt ilinde özellikle Eruh ilçesinde karışık meyve bahçelerinde dağınık şekilde yetiștirilen azımsanmayacak oranda incir ağacı bulunmaktadır. Kapama incir bahçesi sayısı yok denecek kadar az olsa da farklı özelliklerde meyve veren incir ağaçları da bulunmaktadır.

Geleneksel olarak, incir genetik çeşitliliğinin belirlenmesinde morfolojik, fenolojik ve pomolojik kriterler çerçevesinde değerlendirilmektedir. Fenotipik kriterler; iklim, toprak ve kültürel işlemlerden etkilenmektedir. Biyokimyasal, moleküler ve teknolojik analizlerden önce mutlaka morfolojik, fenolojik ve pomolojik kriterler değerlendirmeye alınmalıdır (Ersoy ve ark., 2005; Simsek ve Yildirim, 2010; Gozlekci ve ark., 2011; Caliskan ve ark., 2017; Rodolfi ve ark., 2018). Bu nedenle morfolojik, pomolojik ve fiziko-kimyasal özellikler kullanılarak yapılan tanımlamalar; incir değerlendirmesi, genetik kaynakların envanteri, muhafaza ve 1slah programları için büyük önem taşımaktadır (Podgornik ve ark., 2010; Simsek, 2011; Ersoy ve ark., 2015).

İncir ile ilgili bilimsel çalışmalar olmasına rağmen, farklı meyve özellikleri arasındaki ilişkilerin incelendiği çok az sayıda çalıșma bulunmaktadır. $\mathrm{Bu}$ çalışmada; Siirt ilinin farklı lokasyonlarından örneklenen incir genotiplerinin bazı temel özellikleri arasındaki ilişkiler, parametreler bazında önem düzeyleri ve birbirlerine etki oranlarının belirlenmesi amaçlanmıştır.

\section{Materyal ve Yöntem}

Çalışmada; Siirt ili Merkez ve Eruh lokasyonlarında yer alan, aşılanmamış ve doğal olarak yetişen incir genotipleri bitkisel materyal olarak kullanılmıştır. Siirt yöresinde kapama bahçe niteliğinde incir yetiştiriciliği yapılmamaktadır. Yetiştiricilik diğer meyve türleri ile karışık bahçe niteliğindedir. Aynı zamanda sınır ağacı olanlara da rastlanmıştır. İncelemeye alınan incir ağaçları verimli, periyodisite göstermeyen, 10-25 yaş aralığında olanlar çalışma kapsamına dâhil edilmiştir. Siirt Merkez ilçeden 5 genotip, Eruh ilçesinden 49 genotip olmak üzere toplamda 54 genotip çalışma kapsamında değerlendirmeye alınmıştır. Değerlendirilmeye alınan incir genotiplerinin alındığı yerler Tablo 1'de verilmiştir.

İncir genotiplerine ait örnekler; Uluslararası Bitki Genetik Kaynakları Enstitüsü (IPGRI, International Plant Genetic Resources Institute) tarafından oluşturulmuş, 14'ü kalitatif ve 7'si kantitatif olan 21 kriter kullanılarak değerlendirilmiştir (Anonymous, 2003). Çalışmanın gerçekleştirildiği bahçelerde hasat döneminde, her ağaçtan rastgele olgunlaşmış 10 adet meyve örneği alınmış ve toplanan örnekler pomolojik ve bazı kimyasal özelliklerine bakılmak üzere viyoller ile laboratuvar ortamına alınmıştır. Seçilen incir ağaçlarında bazı fenolojik, morfolojik, pomolojik gözlem, ölçüm ve analizler; Aksoy (1991), Cebeci (1993), Anonymous (2003), Polat ve Caliskan (2007) ve Uzun ve Yarılgaç (2021) tarafından bildirilen esaslara göre yapılmıştır. 
Tablo 1. Incelenen yerel incir genotiplerine ait genel bilgiler

Table 1. General information of the investigated local fig genotypes

\begin{tabular}{cll|cll}
\hline Genotip no & İlçe & Köy & Genotip no & İlçe & Köy \\
\hline E 01 & Eruh & Bağgöze & E 28 & Eruh & Ormanard1 \\
E 02 & Eruh & Kavaközü & E 29 & Eruh & Ormanard1 \\
E 03 & Eruh & Kavaközü & E 30 & Eruh & Ormanard1 \\
E 04 & Eruh & Kemerli & E 31 & Eruh & Erdoğdu \\
E 05 & Eruh & Ormanard1 & E 32 & Eruh & Bağgöze \\
E 06 & Eruh & Kavaközü & E 33 & Eruh & Bağgöze \\
E 07 & Eruh & Bağgöze & E 34 & Eruh & Ormanard1 \\
E 08 & Eruh & Kavaközü & E 35 & Eruh & Ormanard1 \\
E 09 & Eruh & Kemerli & E 36 & Eruh & Ormanard1 \\
E 10 & Eruh & Ormanard1 & E 37 & Eruh & Ormanard1 \\
E 11 & Eruh & Bağgöze & E 38 & Eruh & Ormanard1 \\
E 12 & Eruh & Kavaközü & E 39 & Eruh & Ormanard1 \\
E 13 & Eruh & Kavaközü & E 40 & Eruh & Erdoğdu \\
E 14 & Eruh & Ormanard1 & E 41 & Eruh & Çeltiksuyu \\
E 15 & Eruh & Kavaközü & E 42 & Eruh & Ormanard1 \\
E 16 & Eruh & Kavaközü & E 43 & Eruh & Ormanard1 \\
E 17 & Eruh & Kavaközü & E 44 & Eruh & Erdoğdu \\
E 18 & Eruh & Ormanard1 & E 45 & Eruh & Bağgöze \\
E 19 & Eruh & Kemerli & E 46 & Eruh & Kaş1kyayla \\
E 20 & Eruh & Bağgöze & E 47 & Eruh & Bağgöze \\
E 21 & Eruh & Kaşıkyayla & E 48 & Eruh & Kemerli \\
E 22 & Eruh & Bağgöze & E 49 & Eruh & Kavaközü \\
E 23 & Eruh & Erdoğdu & M 01 & Merkez & Gökçebağ \\
E 24 & Eruh & Kaş1kyayla & M 02 & Merkez & Gökçebağ \\
E 25 & Eruh & Kavaközü & M 03 & Merkez & Gökçebağ \\
E 26 & Eruh & Kemerli & M 04 & Merkez & Gökçebağ \\
E 27 & Eruh & Ormanard1 & M 05 & Merkez & Gökçebağ \\
\hline & & & & &
\end{tabular}

Elde edilen verilerin değerlendirilmesinde; fenotipik verilerin ortalama değerleri kullanılmış, ölçülen özellikler için ortalama, minimum, maksimum, standart sapma (SS) ve varyasyon katsayısı (VK, \%) gibi parametreler hesaplanmıştır. Öznitelik ilişkilerini belirlemek için korelasyon, küme ve temel bileşen analizi yapılmıştır. Analiz ve veri görselleştirmesinde JMP Pro istatistik yazılımı kullanılmıștır. Korelasyon analizi R programında yapmak için "corrplot" paketi (Wei ve Simco, 2017) ve Temel Bileşenler Analizi (PCA, Principal Component Analysis) için "ggplot2" paketi (Wickham, 2016) kullanılmıştır.

İncir seleksiyonlarında tartılı derecelendirme yöntemlerine göre belirlenen kriterler çerçevesinde incelenen genotipler puanlamaya tabi tutulmaktadır. Değerlendirme prensibi olarak temel alınan değiștirilmiş tartılı derecelendirme kriterleri Tablo 2'de sunulmuştur (Aksoy, 1991).

İncelenen incir genotiplerine ilişkin fenolojik, morfolojik ve pomolojik kriterler açısından elde edilen değerler ve bunların genel analizi Gül ve Özrenk (2019)'da yayınlanmıştır. Bu makale kapsamında elde edilen değerlerin öznitelik ilişkileri, temel bileşen analizi ve kümeleme analizleri gerçekleştirilmiştir. Elde edilen 14'ü kalitatif ve 7'si kantitatif olan 21 kriterlerin aralarındaki korelasyonlar incelenmiş olup karşılıklı etkileşimleri ortaya konulmuştur. Aynı zamanda, incir seleksiyonlarının değerlendirilmesinde kullanılan, tartılı derecelendirme kriterleri ve etki seviyeleri JMP Pro istatistik yazllımındaki "Local Data Filter"e tanımlanmak suretiyle ümitvar genotiplerin kolaylıkla belirlenmesine çalışılmıştır.

\section{Bulgular ve Tartıșma}

\subsection{Temel bileşen analizi}

Genotipler arasındaki değişkenlik modellerini belirlemek ve veri setindeki değişkenlerin ayrımını yapmak için PCA yapılmaktadır (Iezzoni ve Pritts, 1991). PCA analizi, sofralık incirlerin (Çalişkan ve Polat, 2008; Saddoud ve ark., 2008; Giraldo ve ark., 2010; Podgornik ve ark., 2010; Hssaini ve ark., 2020) ve yabani incirin (Khadivi-Khub ve Anjam, 2014) fenotipik çeşitliliğini belirlemek için yaygın olarak kullanılmaktadır. $\mathrm{Bu}$ analizin amacı, incelenen genotipleri sinıflandırmak ve inceleme kriterlerinin etki düzeylerini belirlemektir. İncelenen kriterlere ilişkin elde edilen değerler istatistiki analizi gerçekleştirmek için skala değerlerine çevirimleri yapılmıştır (Tablo 3). Aynı zamanda genotiplerin fenolojik, morfolojik ve pomolojik özelliklerine ilişkin tanımlayıcı istatistikler yapılarak Tablo 4'te sunulmuştur. 
Tablo 2. Sofralık incir genotiplerinde tartılı derecelendirme yöntemine göre uygulanan puanlama sistemi Table 2. The scoring system applied according to the weighed grading method in table fig genotypes

\begin{tabular}{|c|c|c|c|}
\hline Özellikler & Göreceli puan & Sinif & Tartıl1 derecelendirme puanı (TDP) \\
\hline \multirow{6}{*}{ Meyve ağırlığı (g) } & \multirow{6}{*}{30} & $\leq 20.0$ & 0 \\
\hline & & $20.1-30.0$ & 2 \\
\hline & & $30.1-40.0$ & 4 \\
\hline & & $40.1-50.0$ & 6 \\
\hline & & $50.1-60.0$ & 8 \\
\hline & & $\geq 60.0$ & 10 \\
\hline \multirow{3}{*}{ Meyve şekil indeksi } & \multirow{3}{*}{15} & $\leq 0.9$ & 8 \\
\hline & & $0.9-1.1$ & 10 \\
\hline & & $\geq 1.1$ & 6 \\
\hline \multirow{3}{*}{ Kabuk çatlaması } & \multirow{3}{*}{10} & Yok & 10 \\
\hline & & Orta & 6 \\
\hline & & Var & 0 \\
\hline \multirow{3}{*}{ Kabuğun soyulma durumu } & \multirow{3}{*}{10} & Kolay & 10 \\
\hline & & Orta & 6 \\
\hline & & Zor & 0 \\
\hline \multirow{3}{*}{ Ostiol açıklığ1 } & \multirow{3}{*}{5} & Kapalı & 10 \\
\hline & & Orta & 8 \\
\hline & & Açık & 6 \\
\hline \multirow{5}{*}{ SÇKM (\%) } & \multirow{5}{*}{15} & $\leq 13.0$ & 2 \\
\hline & & $13.1-16.0$ & 4 \\
\hline & & $16.1-20.0$ & 10 \\
\hline & & $20.1-25.0$ & 8 \\
\hline & & $\geq 25.1$ & 6 \\
\hline \multirow{5}{*}{ TEA $(\%)$} & \multirow{5}{*}{15} & $\leq 0.050$ & 0 \\
\hline & & $0.051-0.125$ & 6 \\
\hline & & $0.126-0.225$ & 8 \\
\hline & & $0.226-0.300$ & 10 \\
\hline & & $\geq 0.301$ & 4 \\
\hline TOPLAM & 100 & & \\
\hline
\end{tabular}

Tablo 3. Genotipler arasında ölçülen kalitatif karakterlerin frekans dağılımı

Table 3. Frequency distribution of qualitative characters measured among genotypes

\begin{tabular}{|c|c|c|c|c|c|}
\hline \multirow{2}{*}{ Niteliksel özellikler } & \multirow{2}{*}{ Dağılım } & \multicolumn{4}{|c|}{ Skala değerleri } \\
\hline & & 1 & 3 & 5 & 7 \\
\hline \multirow{2}{*}{ Ostiol açıklığ1 } & S1klık / \% & $46 / \% 85.18$ & $5 / \% 9.26$ & $3 / \% 5.55$ & - \\
\hline & Skala anlamı & Kapalı & Orta & Açık & \\
\hline \multirow{2}{*}{ Çatlama durumu } & S1klık / \% & $52 / \% 96.30$ & $2 / \% 3.70$ & - & - \\
\hline & Skala anlamı & Yok & Var & - & - \\
\hline \multirow{2}{*}{ Meyve kabuk rengi } & Siklık / \% & $10 / \% 18.52$ & $28 / \% 51.85$ & $6 / \% 11.11$ & $10 / \% 18.52$ \\
\hline & Skala anlamı & Sar1 & Sarımtırak-Yeşil & Mor & Koyu Mor \\
\hline \multirow{2}{*}{ Meyve pulp rengi } & S1klık / \% & $5 / \% 9.26$ & $24 / \% 44.44$ & $25 / \% 46.30$ & - \\
\hline & Skala anlamı & Krem & Pembe & Kirmız1 & - \\
\hline \multirow{2}{*}{ Tat } & Siklık / \% & $9 / \% 16.67$ & $25 / \% 42.30$ & $20 / \% 37.03$ & - \\
\hline & Skala anlamı & Ekşimtrak & Tatl1 & Çok Tatlı & - \\
\hline \multirow{2}{*}{ Verim } & S1klık / \% & $11 / \% 20.37$ & $36 / \% 66.67$ & $7 / \% 12.96$ & - \\
\hline & Skala anlamı & Orta & İyi & Çok İyi & - \\
\hline \multirow{2}{*}{ Çekirdek iriliği } & Siklık / \% & $4 / \% 7.40$ & $28 / \% 54.85$ & $22 / \% 40.74$ & - \\
\hline & Skala anlamı & İri & Orta & Küçük & - \\
\hline \multirow{2}{*}{ Çekirdek miktarı } & Siklık / \% & $15 / \% 27.78$ & $30 / \% 55.56$ & $9 / \% 16.67$ & - \\
\hline & Kod anlamı & $\mathrm{Az}$ & Orta & Çok & - \\
\hline \multirow{2}{*}{ Meyve kabuk dayanıklılığ } & S1klık / \% & $3 / \% 5.56$ & $20 / \% 37.04$ & $31 / \% 57.41$ & - \\
\hline & Skala anlamı & $\mathrm{Az}$ & Orta & İyi & - \\
\hline \multirow{2}{*}{ Soyulma durumu } & Siklık / \% & $2 / \% 3.70$ & $4 / \% 7.41$ & $48 / \% 88.89$ & - \\
\hline & Skala anlamı & Zor & Orta & Kolay & - \\
\hline \multirow{2}{*}{ Meyve kabuk kalınlığ } & S1klık / \% & $7 / \% 12.96$ & $24 / \% 44.44$ & $23 / \% 42.59$ & - \\
\hline & Skala anlamı & İnce & Orta & Kalın & - \\
\hline \multirow{2}{*}{ Ağaç yaş1 } & S1klık / \% & $16 / \% 29.63$ & $23 / \% 42.59$ & $11 / \% 20.37$ & $4 / \% 7.41$ \\
\hline & Skala anlamı & $10-15$ & $16-20$ & $21-25$ & $26>$ \\
\hline \multirow{2}{*}{ Derim süresi } & Siklık / \% & $38 / \% 70.37$ & $15 / \% 27.78$ & $1 / \% 1.85$ & - \\
\hline & Skala anlamı & 25-39 Gün & 40-60 Gün & $>60$ Gün & - \\
\hline \multirow{2}{*}{ Hasat tarihi } & S1klık / \% & $12 / \% 22.22$ & $8 / \% 14.81$ & $34 / \% 62.96$ & - \\
\hline & Skala anlamı & 16-20 Ağustos & 21-24 Ağustos & 25-30 Ağustos & - \\
\hline
\end{tabular}


Tablo 4. Genotiplerin fenolojik, morfolojik ve pomolojik özelliklerine ilişkin tanımlayıcı istatistikler Table 4. Descriptive statistics on phenological, morphological and pomological characteristics of genotypes

\begin{tabular}{|c|c|c|c|c|c|c|c|}
\hline No & Özellik & Birim & Minimum & Maksimum & Ortalama & SS & $\begin{array}{l}\text { VK } \\
(\%)\end{array}$ \\
\hline 1 & SCKM, \% & $\%$ & 9.00 & 32.00 & 18.17 & 5.09 & 28.02 \\
\hline 2 & $\mathrm{pH}$ & - & 3.21 & 4.68 & 3.87 & 0.42 & 10.79 \\
\hline 3 & TEA, $\%$ & $\%$ & 0.14 & 0.54 & 0.29 & 0.10 & 34.00 \\
\hline 4 & Ostiol açıklığ1 (OA) & Skala & 1.00 & 5.00 & 1.41 & 1.06 & 74.99 \\
\hline 5 & Çatlama durumu (ÇD) & Skala & 1.00 & 3.00 & 1.07 & 0.38 & 35.50 \\
\hline 6 & Meyve pulp rengi (MPR) & Skala & 1.00 & 5.00 & 3.74 & 1.31 & 34.91 \\
\hline 7 & Tat & Skala & 1.00 & 5.00 & 3.41 & 1.42 & 41.71 \\
\hline 8 & Verim & Skala & 1.00 & 5.00 & 2.85 & 1.16 & 40.53 \\
\hline 9 & Çekirdek iriliği (Çİ) & Skala & 1.00 & 5.00 & 3.67 & 1.23 & 33.51 \\
\hline 10 & Cekirdek miktarı (CM) & Skala & 1.00 & 5.00 & 2.78 & 1.33 & 47.77 \\
\hline 11 & Meyve kabuk dayanıklılığı (MKD) & Skala & 1.00 & 5.00 & 4.04 & 1.21 & 30.04 \\
\hline 12 & Soyulma durumu (SD) & Skala & 1.00 & 5.00 & 4.70 & 0.90 & 19.21 \\
\hline 13 & Meyve kabuk rengi (MKR) & Skala & 1.00 & 7.00 & 3.59 & 1.97 & 54.75 \\
\hline 14 & Meyve ağırlığı (g) (MA) & $\mathrm{g}$ & 2.31 & 64.82 & 25.33 & 13.75 & 54.28 \\
\hline 15 & Meyve boyu (mm) (MB) & $\mathrm{mm}$ & 20.00 & 52.50 & 34.59 & 7.28 & 21.05 \\
\hline 16 & Meyve eni (mm) (ME) & $\mathrm{mm}$ & 20.00 & 55.00 & 37.42 & 8.17 & 21.83 \\
\hline 17 & Meyve şekil indeksi (MŞİ) & $\mathrm{ME} / \mathrm{MB}$ & 0.83 & 1.45 & 1.09 & 0.13 & 12.26 \\
\hline 18 & Meyve kabuk kalınlığı (MKK) & Skala & 1.00 & 5.00 & 3.59 & 1.38 & 38.43 \\
\hline 19 & Ağacın tahmini yaşı (ATY) & Skala & 1.00 & 7.00 & 3.11 & 1.80 & 57.79 \\
\hline 20 & Derim süresi (DS) & Skala & 1.00 & 5.00 & 1.63 & 1.01 & 62.28 \\
\hline 21 & Hasat tarihi (HT) & Skala & 1.00 & 5.00 & 3.81 & 1.67 & 43.83 \\
\hline
\end{tabular}

SS: Standart sapma, VK: Varyasyon katsayısı

Korelasyon matrisine dayalı PCA analizi kullanılarak, incelenen kriterler için ilk altı bileşenin özdeğerleri (eigen), varyasyon yüzdeleri ve yük katsayıları hesaplanmıştır. Temel bileşen analizinde, nihai çıktının güvenilirliğini korumak için özdeğerleri 1.00'dan fazla olan bileşenler korunmuştur. İlk altı temel bileşenin varyasyonların sirasiyla \% $15.41, \% 11.15$, \% 10.43 , \% 9.80, $\% 7.91$ ve $\% 6.50$ 'sini oluşturduğu ve varyasyonun kümülatif oranının toplam varyansın \% 61.19'una karşılık geldiği bulunmuştur (Tablo 4).

Altı temel bileşen (PC) tarafından çıkarılan varyansın PC1 ve PC2 arasında azaldığını, ancak varyans azalmasının PC2'den itibaren yavaşladı̆̆ını göstermiştir (Tablo 4). PC1 toplam varyansın $\%$ 15.41'ini açıklamış ve meyve boyu (0.43), meyve eni (0.45), meyve ağırlığ $1(0.32)$ ve ostiol açıklığ1 (0.28) ile temsil edilmiş pozitif korelasyonları oluşturmuştur. Titre edilebilir asit $(-0.24)$ negatif korelasyonu temsil etmiştir. PC2 toplam varyansın \% 11.15'ini açıklamış ve pozitif korelasyonlar hasat tarihi (0.36), meyve şekil indeksi (MŞi) (0.37), meyve kabuk dayanıklılığı (0.29) ve pH (0.26) tarafindan, negatif korelasyonlar ise meyve kabuk rengi $(-0.30)$, çatlama durumu $(-0.31)$, tat $(-0.27)$ ve çekirdek iriliği (-0.25) tarafından oluşturulmuştur (Tablo 5).

PC3'te toplam değişkenliğin \% 10.43'ü açıklamıştır. Gözlenen pozitif korelasyonlar; hasat tarihi (0.32), titre edilebilir asitlik (TEA) (0.32), meyve kabuk dayanıklılığı (0.23), meyve eni (0.21) ve meyve kabuk rengi (0.20) değerleri saptanmıştır.
Gözlenen negatif korelasyonlar; suda çözülebilir kuru madde (SÇKM) (-0.43), pH (-0.38) çekirdek iriliği (-0.22), çatlama durumu (-0.22) ve ağacin tahmini yaşı $(-0.18)$ değerleri ile temsil edilmiştir (Tablo 5).

İncelenen genotiplerde etki düzeyi açısından pozitif değerlere sahip kriterler $\mathrm{ME}(0.45)>\mathrm{MB}$ $(0.43)>\operatorname{MŞİ~}(0.37)>\operatorname{HT}(0.36)>\operatorname{MA}(0.32)=$ TEA (0.32) > MKD (0.29) > OA (0.28) > pH (0.26) $>\mathrm{KD}(0.23)>\operatorname{MKR}(0.20)$ siralı etki değerleri PC1, $\mathrm{PC} 2$ ve $\mathrm{PC} 3$ 'te saptanmıştır. İncelenen genotiplerde etki düzeyi açısından negatif değerlere sahip kriterler SÇKM $(-0.43)>\mathrm{pH}(-0.38)>$ ÇD $(-0,31)$ $>$ MKR $(-0.30)>$ Tat $(-0.27)>$ Ç் $(-0.25)$ ve ATY $(-0.18)$ siralı etki değerleri PC1, PC2 ve PC3'te saptanmıştır. PC1 ve PC2 toplam varyansın $\%$ 26.56'sını anlamlandırmaktadır. Fenotipik özellikler açısından genotiplerin ve incelenen kriterlerin konum düzeyleri Şekil 1'de verilmiştir. Grafik incelendiğinde genotiplerin dört tarafa dağıldığı gözlenmektedir. Mevcut bulgular, sofralık incir (Bostan ve ark., 1998; Çalişkan ve Polat, 2008; Podgornik ve ark., 2010) ve yabani incirde (Khadivi-Khub ve Anjam, 2014; Khadivi ve ark., 2018) daha önce rapor edilen çalışmaların sonuçlariyla uyumludur.

Yapılan temel bileşen analizi sonucunda bazı kriterlerde önemli farklılıklar gözlenmiștir. Temel bileşen analizinde etki düzeyleri yüksek olan kriterler pembe dolgu ile belirtilmiş olup, etki değerleriyle (- veya + 0.38-0.44 aralıklarında) karakterize olduğu görülmüştür. İrdelenen 6 temel 
Tablo 5. İncir genotiplerinde temel bileşenlerdeki (PC'ler) varyasyon değerleri

Table 5. Variation values in principal components (PCs) in fig genotypes

\begin{tabular}{|c|c|c|c|c|c|c|}
\hline & \multicolumn{6}{|c|}{ Temel bileșenler (PC) } \\
\hline No & 1 & 2 & 3 & 4 & 5 & 6 \\
\hline Öznitelik (Eigen) değeri & 3.24 & 2.34 & 2.19 & 2.06 & 1.66 & 1.37 \\
\hline Açıklanan varyasyon oranı (\%) & 15.41 & 11.15 & 10.43 & 9.80 & 7.91 & 6.50 \\
\hline Varyasyonun kümülatif oranı (\%) & 15.41 & 26.56 & 36.99 & 46.79 & 54.69 & 61.19 \\
\hline \multirow[t]{2}{*}{ Ki-kare testi önemlilik düzeyi } & $>.0001$ & $>.0001$ & $>.0001$ & $>.0001$ & $>.0001$ & $>.0001$ \\
\hline & \multicolumn{6}{|c|}{ Öznitelik değeri } \\
\hline SÇKM (\%) & 0.20 & 0.14 & -0.43 & -0.02 & 0.14 & 0.23 \\
\hline $\mathrm{pH}$ & 0.18 & 0.26 & -0.38 & 0.11 & 0.01 & 0.10 \\
\hline TEA (\%) & -0.24 & -0.16 & 0.32 & -0.04 & 0.32 & 0.00 \\
\hline Ostiol açıklığ1 & 0.28 & 0.15 & 0.07 & 0.05 & 0.19 & -0.34 \\
\hline Çatlama durumu & 0.16 & -0.31 & -0.22 & 0.21 & 0.12 & -0.22 \\
\hline Meyve pulp rengi & -0.02 & 0.10 & -0.13 & 0.30 & -0.11 & -0.14 \\
\hline Tat & 0.23 & -0.27 & 0.17 & 0.20 & 0.05 & 0.20 \\
\hline Verim & 0.22 & 0.02 & 0.21 & 0.29 & -0.26 & 0.37 \\
\hline Çekirdek iriliği & 0.12 & -0.25 & -0.22 & -0.39 & 0.15 & 0.07 \\
\hline Çekirdek miktarı & -0.14 & 0.09 & -0.10 & 0.45 & -0.13 & -0.22 \\
\hline Meyve kabuk dayanıklılığı & 0.12 & 0.29 & 0.23 & -0.29 & -0.30 & 0.01 \\
\hline Soyulma durumu & 0.14 & -0.03 & -0.18 & -0.02 & 0.00 & 0.48 \\
\hline Meyve kabuk rengi & -0.16 & -0.30 & 0.20 & -0.17 & -0.04 & 0.03 \\
\hline Meyve ağırlı̆̆ 1 (g) & 0.32 & -0.23 & 0.03 & 0.06 & -0.26 & -0.28 \\
\hline Meyve boyu (mm) & 0.43 & -0.22 & 0.19 & 0.08 & 0.05 & 0.04 \\
\hline Meyve eni (mm) & 0.45 & 0.00 & 0.21 & 0.00 & 0.28 & -0.11 \\
\hline Meyve şekil indeksi & 0.09 & 0.37 & 0.04 & -0.15 & 0.44 & -0.23 \\
\hline Meyve kabuk kalınlığ1 & 0.21 & 0.18 & 0.06 & -0.38 & -0.32 & 0.02 \\
\hline Ağacın tahmini yaşı & 0.17 & -0.13 & -0.18 & -0.15 & -0.12 & -0.17 \\
\hline Derim süresi & 0.01 & 0.13 & 0.13 & 0.14 & 0.38 & 0.34 \\
\hline Hasat tarihi & 0.09 & 0.36 & 0.32 & 0.16 & -0.09 & 0.03 \\
\hline
\end{tabular}

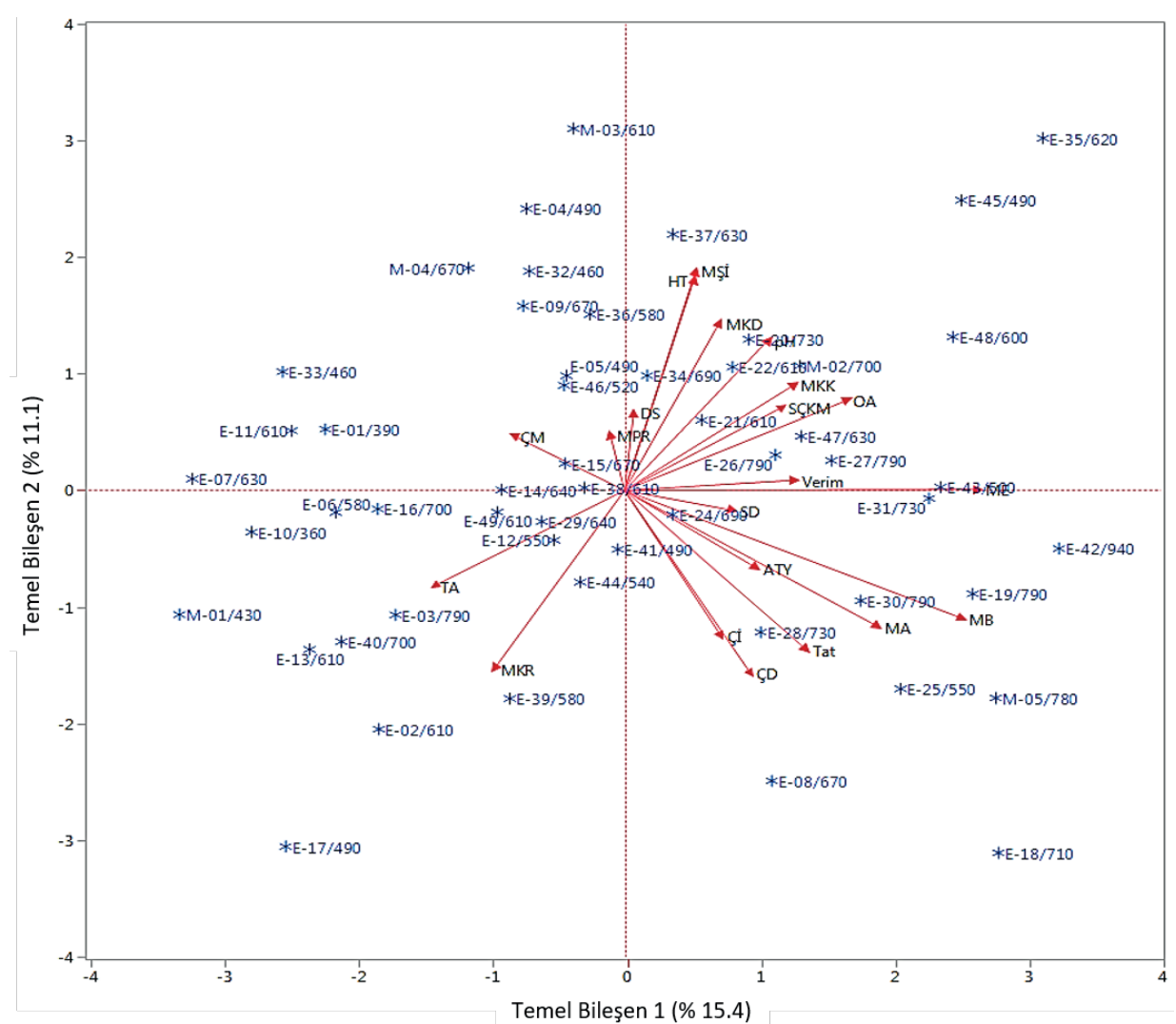

Şekil 1. İncelenen karakterlere dayalı olarak incir genotipleri için ilk temel bileşenin dağılım grafiği Figure 1. Scatter plot of first principal component for fig genotypes based on the characters studied 
bileşendeki kriterlerin almış oldukları öznitelik değerleri azdan çoğa doğru mor rengin tonları ile ifade edilmiştir. Varyasyonu açıklamada tüm temel bileşen seviyelerinde SÇKM (-0.43), pH (0.38), çekirdek miktarı (0.45), meyve boyu (0.43), meyve eni (0.45), meyve şekil indeksi (0.44) ve derim süresi (0.38) en etkili kriterler olmuştur (Tablo 5). Taze olarak tüketilen incirlerin fenotipik tanımlamalarda bilhassa bu parametreler üzerinde durulmasının tanımlamaya etkisi göz önünde bulundurulmalıdır. İncir genotiplerinin ayrılmasında ve tanımlanmasında inceleme kriterlerinin etki düzeylerinin belirlenmesi önemli bulunmuştur. Öznitelik değerleri olarak yüksek bulunan kriterlerin varyasyon oranının fazlalığ1 fenotipik ayrımda etkili olmasına neden olduğu gözlenmiştir.

\subsection{Kümeleme analizi}

Kümeleme analizi ile hedeflenen fenotipik karakterlere dayalı olarak 54 incir genotipi arasındaki konum düzeyini belirlemektir. Çok değişkenli analiz, genotipler arasında benzerlikleri ve farklılıkları yansıtmış olup yüksek polimorfizm göstermiştir. Genotipler arasındaki benzerlikleri ve farklılıkları vurgulamak için JMP programı ile "Hierarchical Clustering-Ward" metodu kullanılarak kümeleme analizi yapılmıştır. Analiz sonucunda genotiplerin yedi gruba ayrıldığ 1 görülmüştür (Şekil 2).
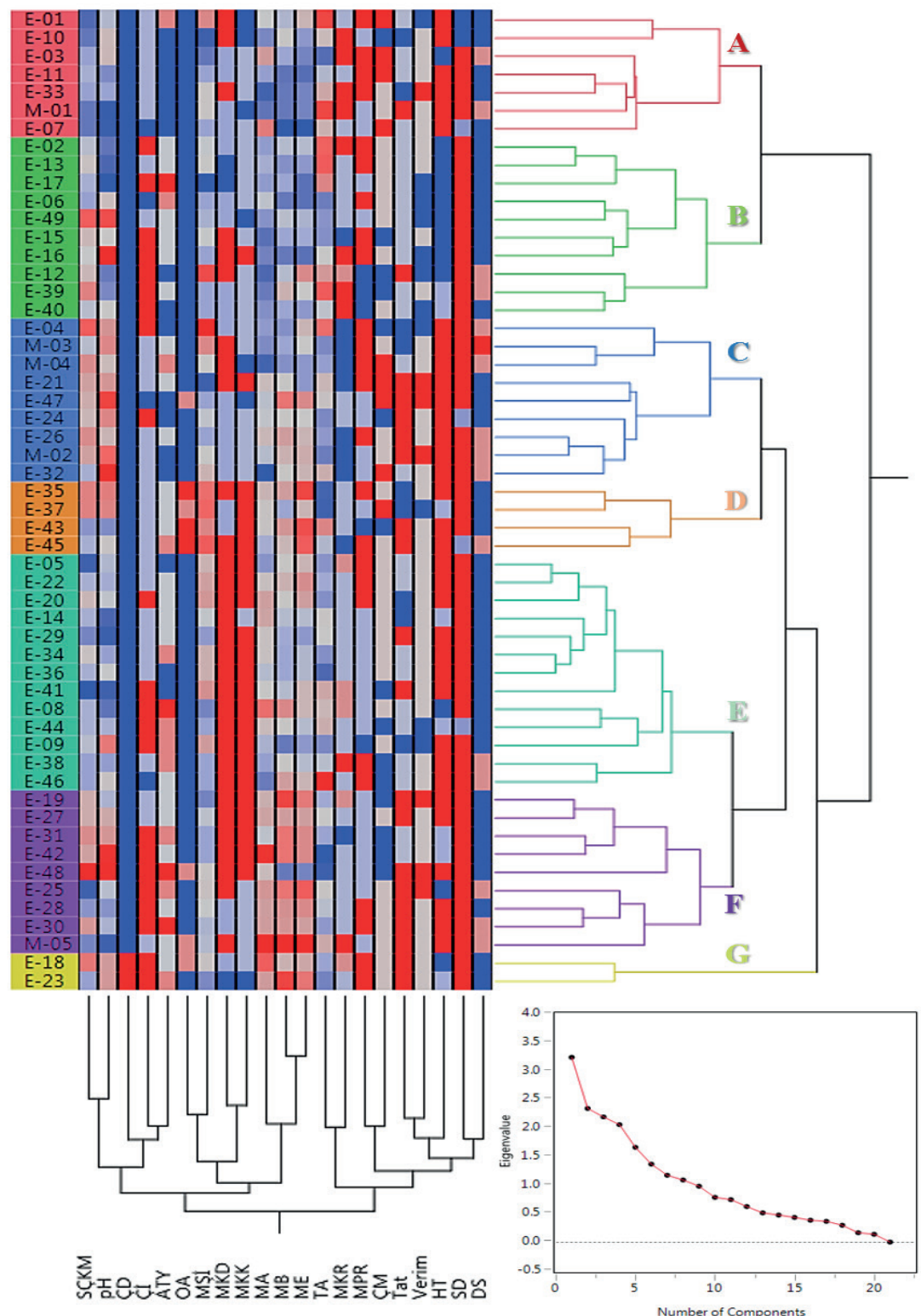

Şekil 2. İncir genotiplerinin morfolojik ve pomolojik özelliklerine göre kümeleme analizi

Figure 2. Cluster analysis of fig genotypes according to morphological and pomological characteristics 
Üstün genotipleri seçmede referans kabul edilen tartılı derecelendirme kriterleri ve aralık değerleri bu puanlama sistemine göre değerlendirilmiştir.
Çalışılan incir genotiplerinin almış oldukları tartılı derecelendirme puanları ve genotiplerin dağılımları Şekil 3'te verilmiştir.

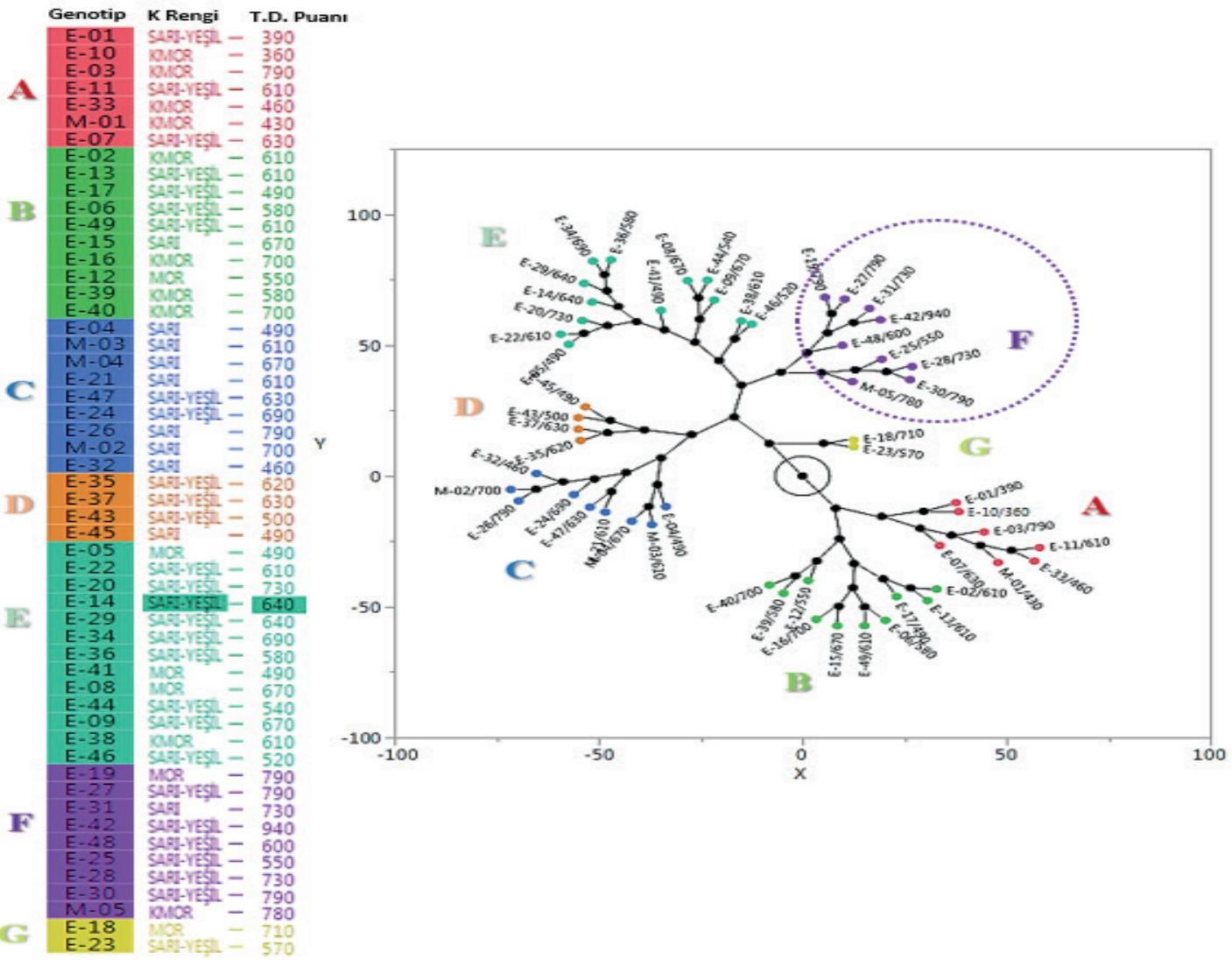

Şekil 3. İncir genotiplerinin kabuk rengi ve tartılı derecelendirme puanlarına göre kümeleme analizindeki konumları

Figure 3. Position of fig genotypes in clustering analysis based on shell color and weighed grading scores

Genotiplerin aldıkları tartılı derecelendirme puanlarına göre dağılım grupları incelendiğinde "F" grubunda yüksek tartılı derecelendirme puanına sahip genotiplerinin toplanmış bulunması oldukça anlamlı bulunmuştur (Şekil 3). Meyve kabuk rengi kriterinden daha baskın konumda, etki oranları yüksek kriterler bulunduğundan kabuk rengine dayalı nispeten dağılım meydana gelmiş olsa da tam bir ayrım gerçekleşmemiştir. Genotipler aynı ekolojik koşullar ve tarımsal uygulamalar altında yetiştirildiğinde, gözlenen varyasyon muhtemel olarak genetikleriyle daha fazla ilgili olacaktır. Fenotipik değerlendirme her zaman için gereklidir; çünkü, genetik kaynakların performansının belirlenmesi ve genetik kaynakların korunması bu sayede mümkün olmaktadır (Giraldo ve ark., 2010).

Korelasyon katsayısı analizine göre, ölçülen değişkenler arasında anlamlı korelasyonlar saptanmıştır (Şekil 4). SÇKM ile pH $(\mathrm{r}=0.54)$, TEA $(\mathrm{r}=-0.31)$, soyulma durumu $(\mathrm{r}=0.29)$ ve meyve kabuk rengi $\quad(\mathrm{r}=\quad-0.32)$ arasında önemli korelasyonların bulunduğu saptanmıştır. $\mathrm{pH}$ değeri ile TEA $(r=-0.50)$ ve meyve kabuk rengi $(r=-0.34)$ arasında önemli korelasyonların bulunduğu saptanmıştır. Titre edilebilir asit miktarı ile meyve ağırlığı negatif ilişkili $(r=-0.30)$ bulunmuştur. Meyve ağırlığı artıkça TEA miktarı düşmektedir. Ostiol açıklığının, meyve eni $(r=0.46)$ ve MŞİ $(\mathrm{r}=0.40)$ ile çok önemli ilişki düzeyi tespit edilmiştir. Meyve eni ve bağlantılı olarak MŞI arttıkça ostiol açıklık düzeyi artma eğilimindedir. Nitekim Khadivi ve ark. (2018) yapmış oldukları çalışmada incirlerde meyve eni, meyve boyu $(\mathrm{r}=0.84)$, ostiol açıklığ $1(\mathrm{r}=0.46)$, meyve ağırlı̆̆ $(r=0.38)$ ile pozitif korelasyon bulduklarını rapor etmişlerdir. İncir meyvelerinde çatlama durumu, meyve kabuk dayanıklılığı ile negatif $(\mathrm{r}=-0.33)$, meyve ağırlığı ile pozitif $(r=0.29)$ ilişki tespit edilmiştir. Meyvede çekirdek miktarı arttıkça kabuk dayanıklılığı azalmakta; meyve ağırlığı arttıkça, 


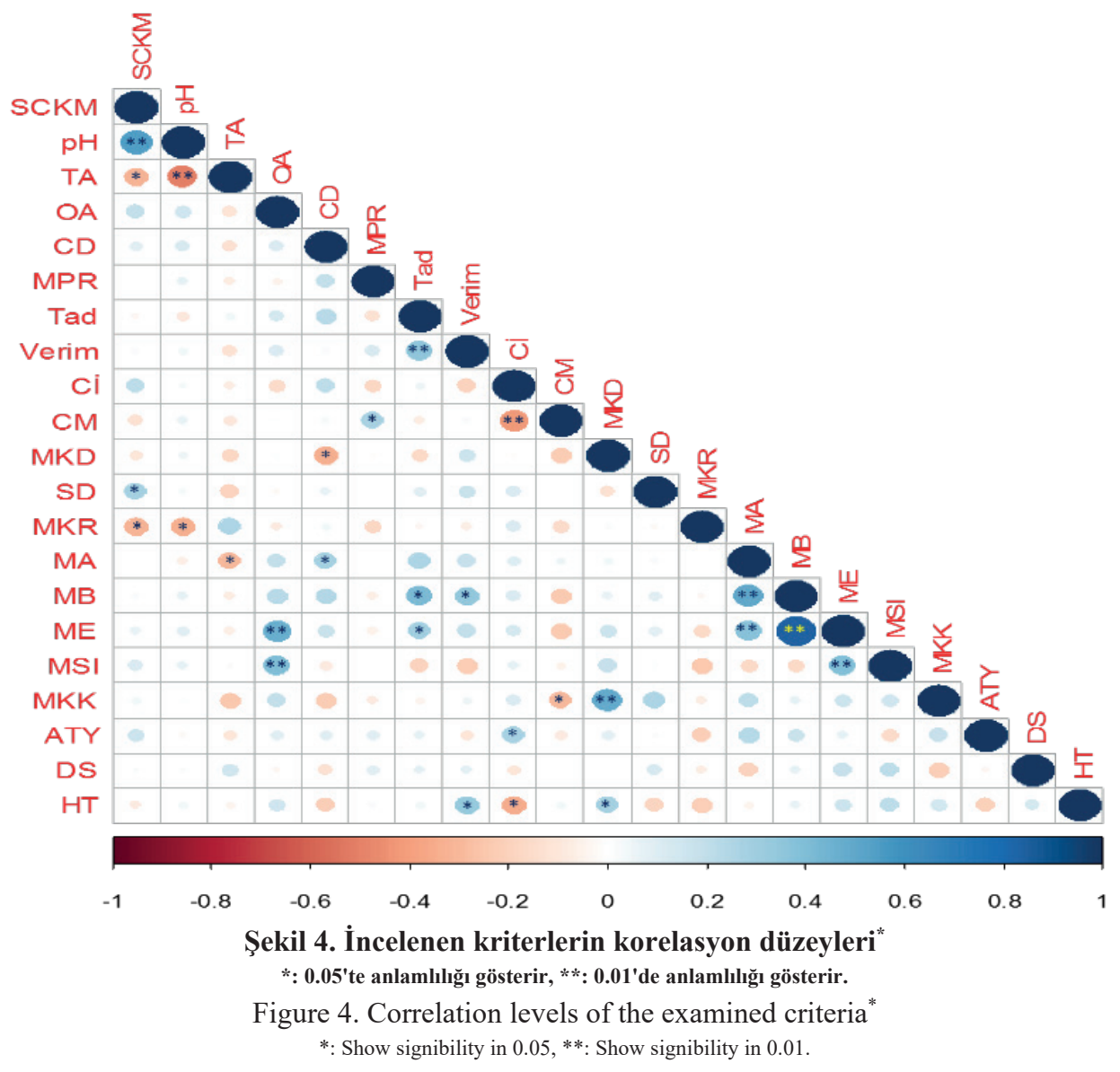

yani hacimce büyüdükçe de incir meyvesinin kabuk dayanıklılığ1 istatistiki anlamda önemli düzeyde artma eğilimindedir. Meyve pulp rengi ile çekirdek miktarı arasında anlamlı pozitif ilişki $(\mathrm{r}=0.27)$ bulunmaktadır. Meyve pulp rengi kremdenkırmızıya doğru değiştikçe çekirdek miktarını da beraberinde arttırmaktadır. Pulp rengi koyu olanların çekirdek miktarı fazla olmakta; bu özellik, genetik potansiyeli ifade etmektedir. Saptanan bu ilişki düzeyleri kullanılarak aralarında anlamlı korelasyon bulunan özelliklerin durumları tahmin edilebilir ve genotipleri karakterize etmek için kullanılabilir. Tat değerleri ile meyve boyu $(\mathrm{r}=0.41)$ ve meyve eni $(\mathrm{r}=0.29)$ arasında anlamlı pozitif korelasyon bulunmaktadır. Meyve kabuk kalınlığı ve meyve kabuk dayanıklılığı arasında çok önemli korelasyon $(r=0.48)$ saptanmıștır. Meyve boyu ile meyve eni ve meyve ağırlığ parametrelerinin arasında çok önemli pozitif korelasyonlar $(r=0.38$ ve $r=0.84)$ belirlenmiştir. İncir seleksiyon çalışmalarında çeşit adayı olabilecek düzeydeki genotiplerin belirlenmesinde korelasyon katsayısı, genotipleri değerlendirmek için önem düzeyi yüksek kriterler hakkında bilgi verebilmektedir (Norman ve ark., 2011; Khadivi-Khub, 2014; Khadivi ve ark., 2018).

\section{3. Üstün nitelikteki çeşitlerin tanımlanması}

Üzerinde çalışılan genotiplere ait verilerin genel değerlendirilmesi ve üstün nitelikte olanları tespit etme maksatlı istatistik değerlendirmelerde "JMP Pro" programinda bulunan "Local Data Filter" kullanılmıştır. Uygulanacak olan bu filtrelerde tartılı derecelendirme puanlama sisteminde belirtilen; meyve ağırlığı, meyve şekil indeksi, ostiol açıklığı, soyulma durumu, SÇKM ve TEA parametrelerinin kriter aralıkları tanımlanmıştır (Şekil 5).

$\mathrm{Bu}$ filtrenin çalıştırılması ile ikili dendogram elde edilmiştir. Elde edilen dendogramda ümitvar incir genotipleri görülmektedir (Şekil 5). Ümitvar incir genotipleri içinde tartılı derecelendirmede 940 puanla en yüksek değeri alan E-42 (Eruh yöresi) genotipi olmuştur. Bunu E-19, E-20, E-26, E-27 ve $\mathrm{E}-30(\mathrm{TDP}=790)$ takip etmiştir. E-20 genotipi de 730 TDP ile tespit edilen son genotiptir. Ümitvar görülen incir genotiplerinin görselleri Şekil 6'da verilmiştir.

$\mathrm{Bu}$ çalıșma neticesinde elde edilen veriler üzerinden herhangi bir tartılı derecelendirme tablosu oluşturmaksızın öne çıkan genotipler tespit edilebilmekte olup, yapılacak incir seleksiyon 

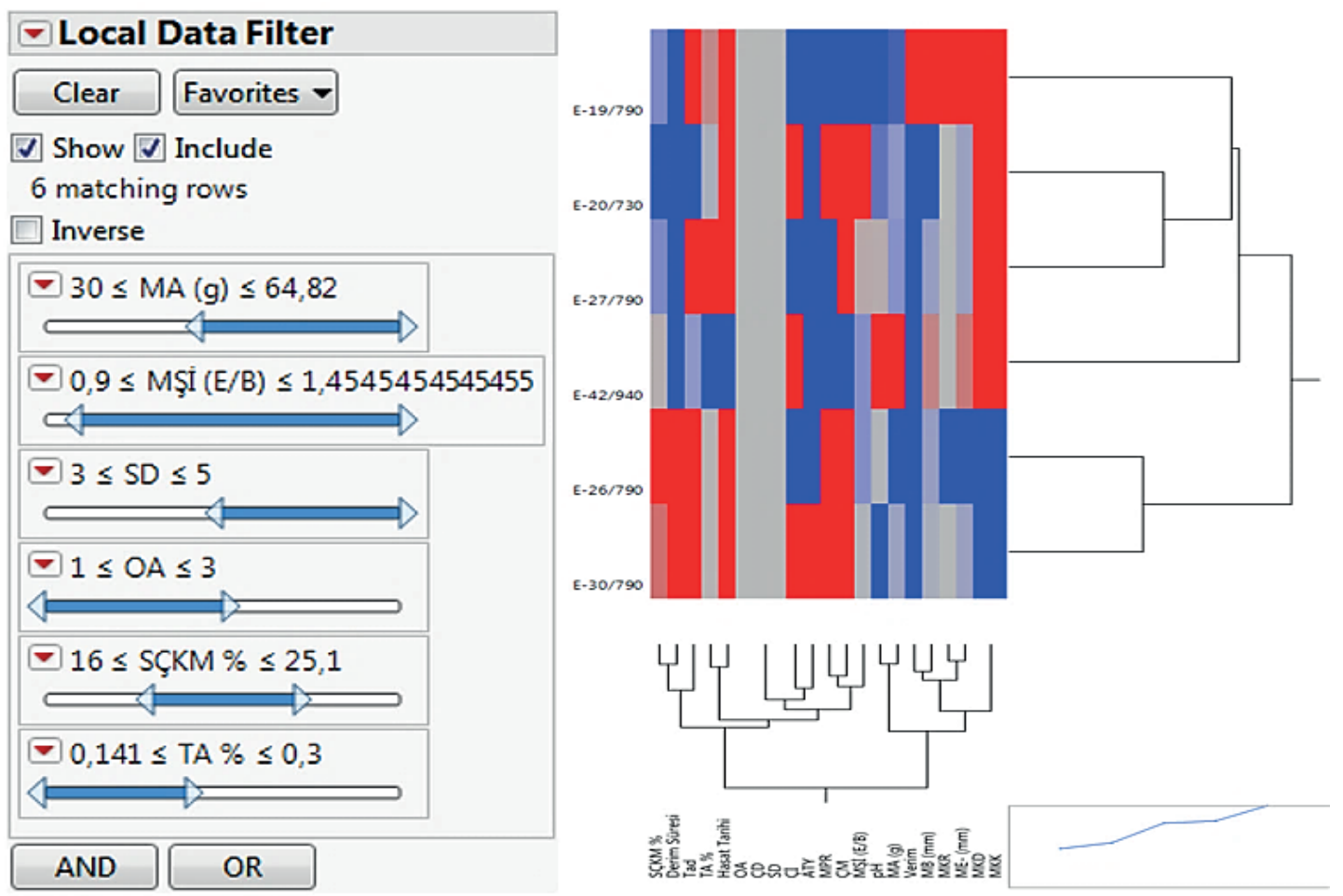

Şekil 5. Data filter uygulanması, üstün nitelikli genotipler ve konum düzeyleri Figure 5. Data filtering, superior genotypes and location levels
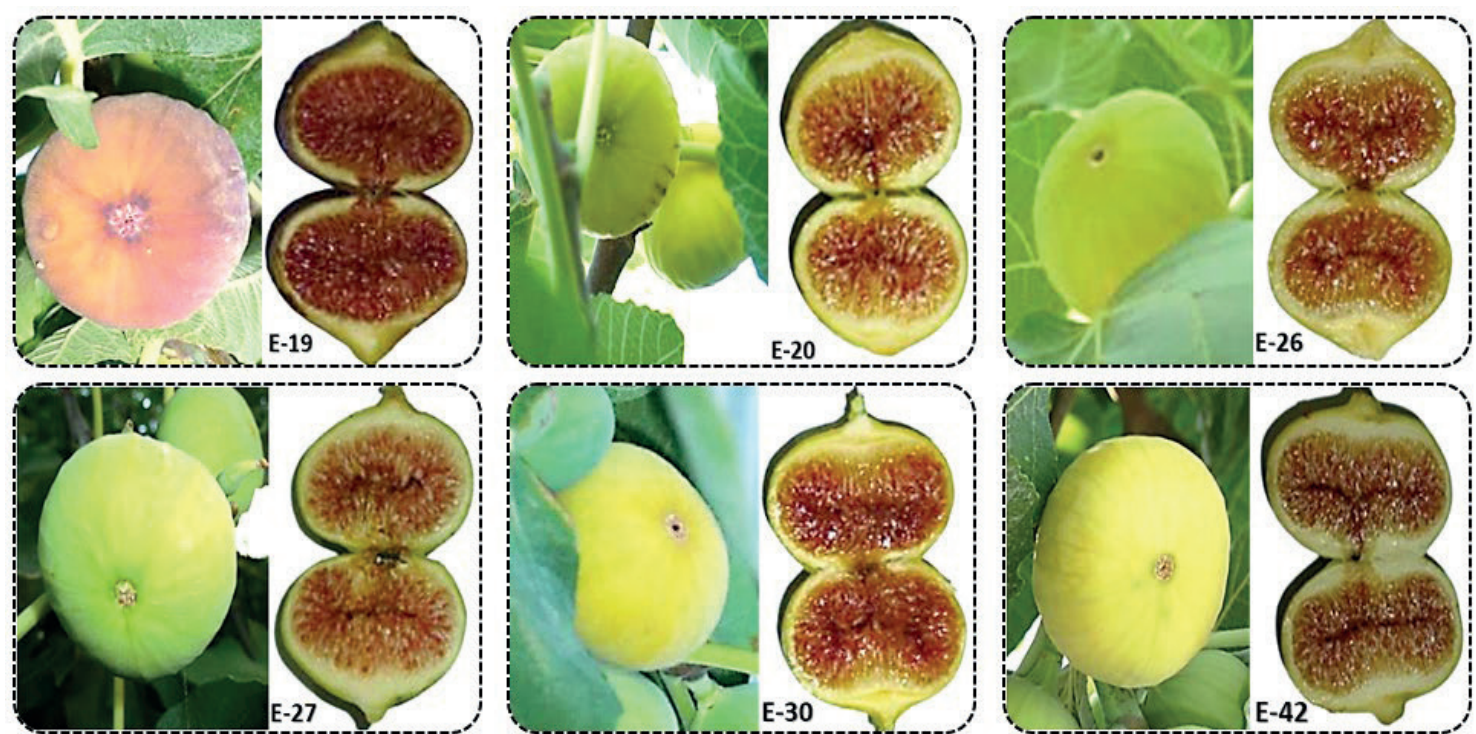

Şekil 6. Seçilen sofralık incir genotipleri

Figure 6. Selected table fig genotypes

çalışmalarında kullanılabilirliği uygun bulunmuştur. Sofralık veya kurutmalık incir seleksiyonlarında tartılı derecelendirme kriterleri JMP programinın "Local Data Filter" modülüne tanımlanarak öne çıkan genotipleri ve bunların birbirine olan mesafelerini ortaya koymak mümkün görülmektedir. Seçilen genotiplerin birbirine yakınlık ve uzaklığını ifade eden mesafe matrisi Tablo 6'da verilmiştir. Aynı zamanda Elbow yöntemine göre "K Means Cluster" gruplandırması yapılmıştır. Yapılan gruplama neticesinde üç temel kümeleme grubu oluşmuştur. Ümitvar olarak tespit edilen genotiplerin 1. kümeleme grubunda yer alması anlamlı bulunmuştur (Şekil 7). 
Tablo 6. Seçilen genotiplerin mesafe matriksi Table 6. Distance matrix of selected genotypes

\begin{tabular}{ccccccc}
\hline & E-19 & E-20 & E-26 & E-27 & E-30 & E-42 \\
\hline E-19 & 0 & & & & & \\
E-20 & 6.80 & 0 & & & & \\
E-26 & 7.19 & 6.16 & 0 & & & \\
E-27 & 4.79 & 4.38 & 4.96 & 0 & & \\
E-30 & 6.79 & 5.68 & 3.80 & 5.33 & 0 & \\
E-42 & 6.33 & 6.28 & 7.27 & 5.91 & 7 & 0 \\
\hline
\end{tabular}

Çalışma neticesinde incelenen kriterlerin mekanizması, etki düzeyi, aralarındaki korelasyonlar ve aralarındaki mesafe korelasyonları ortaya konulmuştur. Seçilen genotiplerin birer tanesi "C" ve "D" grubunda diğer dört tanesinin " $F$ " grubunda toplanması önemli bulunan bir diğer bulgudur. E-26 ve E-20 genotiplerinin kümeleme analizinde ayrı gruplarda olmasının meyve ağırlığ ve SÇKM kriterlerinin sofralık incir tartılı derecelendirme puanlama sistemindeki etki oranlarından kaynaklandığı düşünülmektedir.

Seçilen genotiplerin kabuk rengi 4 genotipte "yeşil-sarı" birer genotipte de "sarı" ve "mor" renklerde olduğu görülmüştür. Renk dağılımlarının farklı gruplarda toplanmasina neden olan "meyve kabuk rengi” etki değerinin diğer baskınlığı yüksek kriterlere göre kümeleme analizinde daha düşük etki değerinden kaynaklandığı düşünülmektedir.

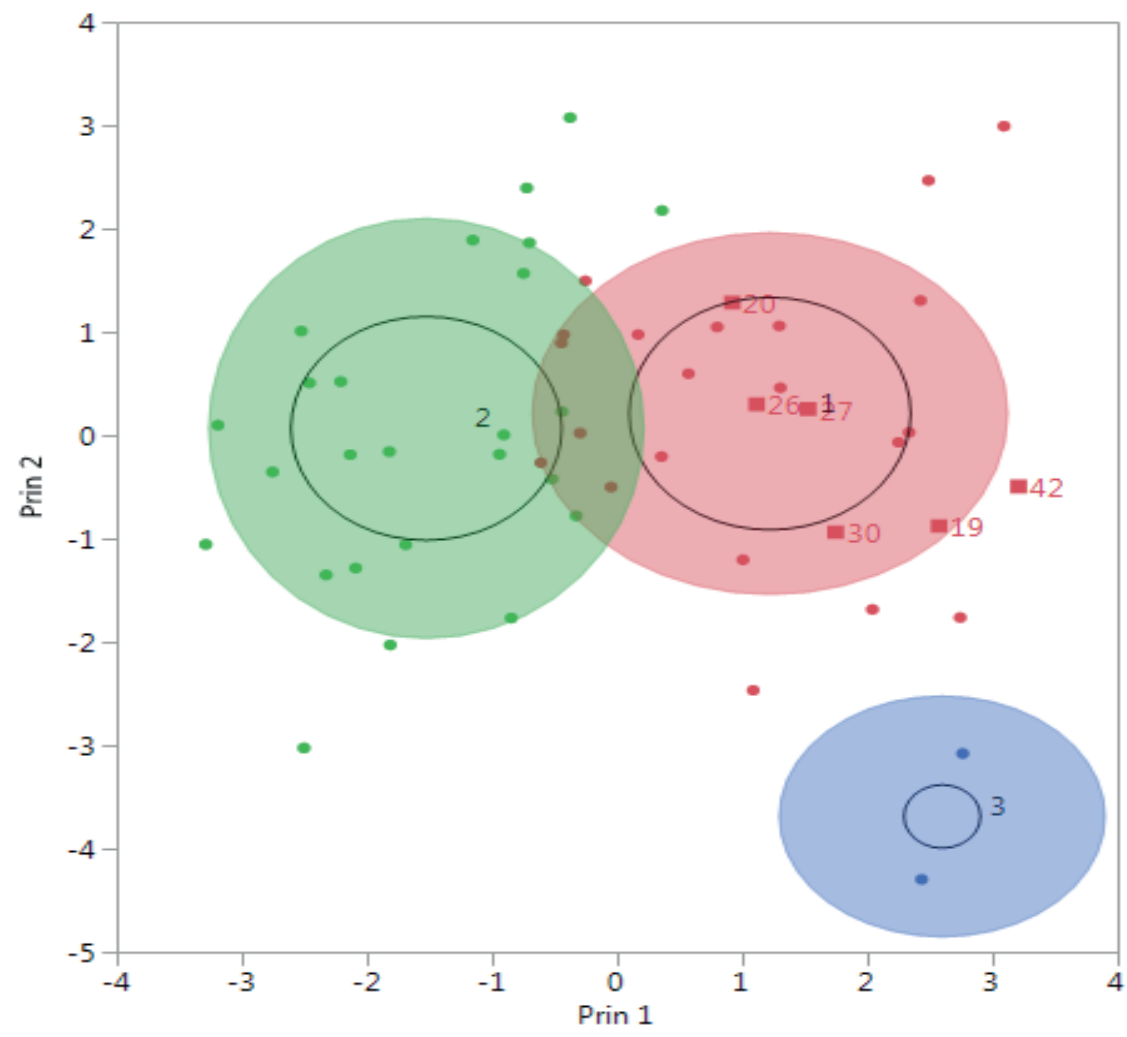

Şekil 7. İncir genotiplerinin "K Means Cluster" grafiği

Figure 7. "K Means Cluster" graph of fig genotypes

\section{Sonuçlar}

Yüksek düzeyde ayırım yapabilen kriterlerin seçimi, etkili bir fenotipik karakterizasyon ve kaynakları optimize etmek için oldukça önemlidir. Bu husus, dünya çapında tanımlanmış yüzlerce genotipe sahip incir gibi birçok homonimin gözlemlenebildiği bir meyvede özellikle önemlilik arz etmektedir. Siirt yöresinde meyve kalitesi açısından ümitvar düzeyde 6 adet incir genotipinin bulunduğu belirlenmiştir. Kaliteli bulunan incir genotiplerinin doğrudan bölgede yetiştirilmesi hususunda artık yöre genotiplerinin isimleri verilebilir nitelik kazanmıştır. Aynı zamanda dolaylı olarak 1slah programlarında kullanılabilecek incir genotiplerinin çeşit özelliklerinin ve birbirine olan konumlarının bu çalışmayla ortaya konulması büyük önem arz etmektedir. İncelenen incir popülasyonunda farklı olgunlaşma zamanlarına sahip genotiplerin varlığ 1 sonraki yıllarda yapılacak olan çalışmalarla pazarda taze incir bulunma süresini uzatacaktır. Bu çalışma 
aynı zamanda incir genotipleri arasında var olan geniş pomolojik çeşitliliği de ortaya koymaktadır. Mevcut çalışmanın sonuçları, incir genetik kaynağının uygun bir şekilde yönetilmesi ve korunması bağlamında özgün bir değere sahiptir.

\section{Kaynaklar}

Aksoy, U., 1991. Descriptors for Fig (Ficus carica L. and Related Ficus sp.). Ege University, Faculty of Agriculture, Department of Horticulture, Bornova, İzmir, Turkey.

Aksoy, U., Can, H.Z., Misirli, A., Kara, S., Seferoglu, G., Sahin, N., 2003. Fig (Ficus carica L.) selection study for fresh market in western Turkey. Acta Horticulture, 605: 197-203.

Anonymous, 2003. Descriptors for fig (Ficus carica L.). International plant genetic resources institute (IPGRI), Rome, Italy and International Center for Advanced Mediterranean Agronomic Studies (CIHEAM), Paris.

Bostan, S.Z., İslam, A., Aygun, A., 1998. A Study on pomological characteristics of local fig cultivars in northern Turkey. Acta Horticulturae, 480: 71-74.

Caliskan, O., Bayazit, S., Ilgin, M., Karatas, N., 2017. Morphological diversity of caprifig (Ficus carica var. caprificus) accessions in the eastern Mediterranean region of Turkey: Potential utility for caprification. Scientia Horticulturae, 222: 46-56.

Cebeci, E., 1993. Çukurova ve Ege incir klon ve çeşitlerinde meyve doğuşları, çiçek organlarının gelişimi ve döllenme biyolojileri üzerinde çalışmalar. Yüksek lisans tezi, Çukurova Üniversitesi, Fen Bilimleri Enstitüsü, Adana.

Crisosto, H., Ferguson, L., Bremer, V., 2011. Fig (Ficus carica L.) Postharvest Biology and Technology of Tropical and Subtropical Fruits. Woodhead Publishing Series in Food Science, Technology and Nutrition, pp. 134-158.

Çalişkan, O., Polat, A.A., 2008. Fruit characteristics of fig cultivars and genotypes grown in Turkey. Science Horticulture, 115(4): 360-367.

Ercisli, S., Tosun, M., Karlidag, H., Dzubur, A., Hadziabulic, S., Aliman, Y., 2012. Color and antioxidant characteristics of some fresh fig (Ficus carica L.) genotypes from northeastern Turkey. Plant Foods for Human Nutritions, 67(3): 271-276.

Ersoy, N., Gözlekçi, S., Kaynak, L., Dal, B., Yazici, K., 2005. Relationships among the shoot, leaf and fruit growth of some fig (Ficus carica L.) cultivars grown in Antalya. Third International Symposium on Fig, 16-20 May, Vilamoura, Algarve, Portugal, pp. 143148.

Ersoy, N., Gözlekçi, S., Yilmaz, S., 2015. Fig (Ficus carica L.) fruit: some physical and chemical properties. V. International Symposium on Fig, 31 August-3 September, Napoli, Italy, pp.329-334.

Falistocco, E., 2009. Presence of triploid cytotypes in the common fig (Ficus carica L.). Genome, 52(11): 919925.
Frodin, D.G., 2004. History and concepts of big plant genera. Taxon, 53(3): 753-776.

Giraldo, E., López-Corrales, M., Hormaza, J.I., 2010. Selection of the most discriminating morphological qualitative variables for characterization of fig germplasm. Journal of the American Society for Horticultural Science, 135(3): 240-249.

Gozlekci, S., 2010. Selection studies on fig (Ficus carica L.) in Antalya province of Turkey. African Journal of Biotechnology, 9(46): 7857-7861.

Gozlekci, S., Kafkas, E., Ercisli, S., 2011. Volatile compounds determined by HS/GC-MS technique in peel and pulp of fig (Ficus carica L.) cultivars grown in Mediterranean region of Turkey. Notulae Botanicae Horti Agrobotanici Cluj-Napoca, 39(2): 105-108.

Gül, Y., Özrenk, K., 2019. İncir (Ficus carica L.) genetik kaynaklarının belirlenmesine yönelik bir çalışma: Türkiye, Siirt yöresi. Türkiye Tarımsal Araştırmalar Dergisi, 6(3): 328-335.

Gürbüz, N., Uluişik, S., Frary, A., Doğanlar, S., 2018. Health benefits and bioactive compounds of eggplant. Food Chemistry, 268: 602-610.

Hssaini, L., Hanine, H., Razouk, R., Ennahli, S., Mekaoui, A., Ejjilani, A., Charafi, J., 2020. Assessment of genetic diversity in Moroccan fig (Ficus carica L.) collection by combining morphological and physicochemical descriptors. Genetic Resources and Crop Evolution, 67(2): 457474.

Iezzoni, A.F., Pritts, M.P., 1991. Applications of Principal Component Analysis to horticultural research. HortScience, 26(4): 334-338.

Ilgın, M., 1995. Kahramanmaraş Bölgesi’nde incir seleksiyonu ve selekte edilen bazı önemli tiplerin meyve doğuşları ve döllenme biyolojileri üzerinde çalışmalar. Doktora tezi, Çukurova Üniversitesi, Fen Bilimleri Enstitüsü, Adana.

Kaşka, N., Küden, A.B., Cebeci, E., 1992. Çukurova Bölgesinde yetiştirilen bazı incir çeşitlerinde meyve doğuşları ve derim tarihlerinin saptanması. Türkiye 1. Ulusal Bahçe Bitkileri Kongresi, 13-16 Ekim, Cilt I, İzmir, s. 277-280.

Khadivi, A., Anjam, R., Anjam, K., 2018. Morphological and pomological characterization of edible fig (Ficus carica L.) to select the superior trees. Scientia Horticulturae, 238: 66-74.

Khadivi-Khub, A., Anjam, K., 2014. Characterization and evaluation of male fig (caprifig) accessions in Iran. Plan Systematics and Evolution, 300(10): 21772189.

Kislev, M.E., Hartmann, A., Bar-Yosef, O., 2006. Early domesticated fig in the Jordan Valley. Science, 312: 1372-1374.

Norman, P.E., Tongoona, P., Shanahan, P.E., 2011. Determination of interrelationships among agrmorphological traits of yams (Discorea spp.) using correlation and factor analyses. Journal of Applied Biosciences, 45: 3059-3070. 
Podgornik, M., Vuk, I., Vrhovnik, I., Mavsar, D.B., 2010. A survey and morphological evaluation of fig (Ficus carica L.) genetic resources from Slovenia. Scientia Horticulturae, 125(3): 380-389.

Polat, A.A., Caliskan, O., 2007. Fruit characteristics of table fig (Ficus carica) cultivars in subtropical climate conditions of the Mediterranean region. New Zealand Journal of Crop and Horticultural Science, 36(2): 107-115.

Rodolfi, M., Ganino, T., Chiancone, B., Petruccelli, R., 2018. Identification and characterization of Italian common figs (Ficus carica) using nuclear microsatellite markers. Genetic Resources and Crop Evolution, 65(5): 1337-1348.

Saddoud, O., Baraket, G., Chatti, K., Trifi, M., Marrakchi, M., Salhi-Hannachi, A., Mars, M., 2008. Morphological variability of fig (Ficus carica L.) cultivars. International Journal of Fruit Science, 8(12): $35-51$

Simsek, M., 2009. Evaluation of selected fig genotypes from south east Turkey. African Journal of Biotechnology, 8(19): 4969-4976.

Simsek, M., 2011. A study on selection and identification of table fig types in east edge of Firat River. Asian Journal of Animal Veterinary Advances, 6(3): 265273.
Simsek, M., Gülsoy, E., Kırar, M., Turgut, Y., Yücel, B., 2017. Identification and selection of some female fig (Ficus caria L.) genotypes from Mardin province of Turkey. Pakistan Journal of Botany, 49(2): 541-546.

Simsek, M., Yildirim, H., 2010. Fruit characteristics of the selected fig genotypes. AfricanJournal of Biotechnology, 9(37): 6056-6060.

Solomon, A., Golubowicz, S., Yablowicz, Z., Grossman, S., Bergman, M., Gottlieb, H.E., Altman, A., Kerem, Z., Flaishman, M.A., 2006. Antioxidant activities and anthocyanin content of fresh fruits of common fig (Ficus carica L.). Journal of Agricultural and Food Chemistry, 54(20): 7717-7723.

Tous, J., Ferguson, L., 1996. Mediterranean fruits. In: J. Janick (Ed.), Progress in New Crops, ASHS Press, Arlington, USA, pp. 416-430.

Uzun, S., Yarılgaç, T., 2021. Germencik (Aydın) ilçesinde yetiştirilen Sarılop incirlerinde (Ficus carica L.) klon seleksiyonu. Uluslararası Tartm ve Yaban Hayatı Bilimleri Dergisi, 7(1): 1-8.

Wei, T., Simco, V., 2017. R Package "Corrplot": Visualization of a Correlation matrix (Version 0.84).

Wickham, H., 2016. Ggplot2: Elegant Graphics for Data Analysis. Springer-Verlag, New York. 